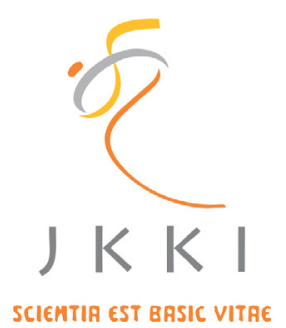

Jurnal Kedokteran dan Kesehatan Indonesia

Indonesian Journal of Medicine and Health

Journal homepage : www.journal.uii.ac.id/index.php/jkki

\title{
Universal Health Coverage and a pledge to empowering persons with disabilities and ensuring inclusiveness and equality; how does this year's theme benefit the deaf/dumb
}

Juliet Mwale Musabula*1

${ }^{1}$ Police officer at Zambia Police Service and Guest lecturer University of Zambia and National Institute of Public Administration, Zambia

\begin{tabular}{|c|c|}
\hline & GUEST EDITORIAL \\
\hline ARTICLE INFO & The 2030 Agenda, whose fundamental principle is dignity and \\
\hline $\begin{array}{l}\text { *Corresponding author: } \\
\text { jmusabula@hotmail.com }\end{array}$ & $\begin{array}{l}\text { at building a peaceful and prosperous world where all including } \\
\text { people living with a disability can fully enjoy their human rights. }{ }^{1} \text { The }\end{array}$ \\
\hline DOI : 10.20885/JKKI.Vol9.Iss3.art1 & $\begin{array}{l}\text { launch of the Universal Health Coverage (UHC) in } 2014 \text { to succeed the } \\
\text { Millennium Development Goals as a global health objective is therefore }\end{array}$ \\
\hline $\begin{array}{l}\text { Copyright @2018 Authors. } \\
\text { This is an open access article } \\
\text { distributed under the terms } \\
\text { of the Creative Commons At- } \\
\text { tribution-NonCommercial } 4.0 \\
\text { International Licence (http:// } \\
\text { creativecommons.org/licences/ } \\
\text { by-nc/4.0/). }\end{array}$ & $\begin{array}{l}\text { timely to reduce health access challenges especially for the marginalised } \\
\text { populations such as the persons with disability. At its core, UHC } \\
\text { emphasises that people should be able to gain access to the healthcare } \\
\text { services without experiencing financial risk. } \\
\text { Creating more accessible and inclusive services and facilities help to } \\
\text { minimise the effects of disability and enable people with disability to } \\
\text { reach their full potential and in turn contribute to national development. } \\
\text { In line with the Vision } 2030 \text { and Sustainable Development Goals (SDGs), } \\
\text { the UHC is also anchored on the principles that promote equitable access, } \\
\text { efficiency, quality, inclusiveness and availability of health services for all. } \\
\text { For the deaf, this can only be meaningful if the communication barrier can } \\
\text { be removed. }\end{array}$ \\
\hline
\end{tabular}

Since 1992, December 3rd of every year, the world commemorates the International Day of Persons with Disability (IDPD). During the commemorations, governments all over the world reaffirm their commitment to working with persons with disability to improve their health and well-being. ${ }^{5}$ Thus, this year's International Day of Persons with Disability was "empowering persons with disabilities and ensuring inclusiveness and equality" was premised on both the vision 2030 agenda and the UHC principles.

The term disability encompasses some conditions such as physical, sensory, psychiatric, neurological, cognitive and intellectual hence other situations, the management of these conditions differs both medically and socially. ${ }^{6}$ For instance, those with missing limbs may require assistance with mobility while those with a sensory or neurological impairment may require other forms of assistance. It is a well-known fact that persons with disabilities have more healthcare needs than others and are more likely to be more vulnerable to the impact of low quality and limited access to healthcare services than others. ${ }^{5}$ However, no one single strategy may address all the challenges that persons with disability face. ${ }^{7}$ Therefore, as governments globally embark on ambitious programs which reaffirm their commitment to the rights of people with disability, there is a need to have disability specific approaches. ${ }^{3}$

For example, speech and hearing impairment persons commonly known as deaf and dumb faces communication barrier as most often, they cannot communicate effectively with the general population due to various reasons. Some of the reasons include illiteracy; where one cannot use the pen and paper 
to communicate; lack of knowledge in sign language by both service providers and the deaf clients and lack of trained interpreters in health facilities. The general population is also not oriented in the use of sign language to effectively communicate with the deaf and dumb when they come to seek services. This is despite having a fully functioning sign language as the firs language for the deaf persons.

There is overwhelming evidence that many healthcare barriers for the deaf/dumb stem from health care providers' lack of knowledge to communicate using the sign language..$^{8-10}$ The same is also true for other services. Available evidence also shows that the deaf/dumb persons do not view themselves as having a disability because most often they have sight and are mobile which makes it easy for them to seek services though even if they did, they are unable to communicate effectively with the services providers. ${ }^{10,11}$ Thus, deaf are likely to suffer limited access to most public services including health care due to fear and frustration of being misunderstood by the health care providers.

Communication is a fundamental requirement and a vital component of any human relationships. Effective communication is defined as a two-way process where messages are passed from one person to the other using a variety of symbols that are familiar to both parties such as spoken words, manual signs, text, gestures, and or graphics, until the message is correctly understood by both parties. ${ }^{11,12}$ Communication barriers, on the other hand, prevent or distort effective communication between two parties.

Therefore, as governments are developing policies on UHC and inclusive health services as outlined in this year's, theme for IDPD, the needs of the deaf clients should clearly be guided by policy directives aimed at addressing fear and frustration due to their inability to communicate with health care providers whenever they seek health services. ${ }^{6}$ For example, governments should develop policies that would allow members of the public and healthcare providers to have basic knowledge in sign language to smooth communication with deaf clients. The governments can also increase the number of positions for interpreters in health facilities even though having interpreters is an infringement to the right to privacy. ${ }^{13}$ For instance, it is frustrating on the part of the deaf patient to have an interpreter present as they conduct a gynaecological examination or disclosure of private information such as sexually transmitted infections or HIV/AIDS results.

The call for UHC and the pledge of "leaving no one behind" is indeed timely in addressing the communication challenges the deaf/dumb persons face. The two ideologies if harnessed by good policies can undoubtedly improve the lives of the persons with a disability like the deaf/dumb. ${ }^{3}$ Some of the mitigating factors to this problem include policies that compel the teaching of primary sign language in all schools and health training institutions to easy communication between the service providers and the deaf/dump persons. This means will not only reduce the cost for hiring interpreters who would need to be on the government payroll but also promote confidentiality for the deaf patient/ client. Also, apart from reducing the cost of hiring the interpreters, removing a third person in the line of communication between the deaf/dumb and their carers will help reduce medical errors and create a trusting relationship between the two parties. ${ }^{9}$

In conclusion, access to health services by the deaf/dumb persons will continue to be hampered due to communication challenges if health professionals continue to lack the skills to communicate using sign language. If the situation is left its current form, then the call for inclusive health services and good health for all will remain the unattainable reality.

\section{REFERENCES}

1. Ooms G, Latif LA, Waris A, Brolan CE et al. Is universal health coverage the practical expression of the right to health care? BMC International Health and Human Rights [Internet]. 2014;14(3):1-7.

2. World Health Organisation. Arguing for universal healthcare coverage. Geneva Switzerland. 2013.

3. United Nations. Transforming our world: The 2030 agenda for sustainable development. 2014.

4. Ooms G, Brolan C, Eggermont N, Eide A, Flores W, Forman L, et al. Universal health coverage anchored in the right to health. Bulletin of the World Health Organization. 2013;91(1):1-2. 
5. United Nations Department of Economic and Social Affairs. Realization of the sustainable development goals by, for and with persons with disabilities. Disability and the 2030 Agenda for Sustainable Development. 2018.

6. Disability Services Commission. Disability access and inclusion plans 2016-2017 progress Report. Government of Western Australia. 2018.

7. World Bank. Healthy systems for universal health coverage - a joint vision for healthy lives. Geneva Switzerland. 2017.

8. Hoang L, LaHousse SF, Nakaji MC, Sadler GR. Assessing deaf cultural competency of physicians and medical students. Journal of Cancer Education. 2011;26(1):175-82.

9. Kuenburg A, Fellinger P, Fellinger J. Health care access among deaf people. Journal of Deaf Studies and Deaf Education. 2016;21(1):1-10.

10. Munoz-Baell IM, Ruiz MT. Empowering the deaf. Let the deaf be deaf. Journal of Epidemiology and Community Health. 2000;54(1):40-4.

11. Riddle I, Romelczyk S, Sparling E. Effective communication for health care providers. Newark, DE. Center for Disabilities Studies, University of Delaware. 2011.

12. Scheier DB. Barriers to health care for people with hearing loss: A review of the literature. Journal of New York Nurses Association. 2009;40(1):4-10.

13. Chaveiro N, Porto CC, Barbosa MA. The relation between deaf patients and the doctor. Brazilian Journal of Otorhinolaryngology. 2009;75(1):147-50. 